\title{
Analysing Lee's Hypotheses of Migration in the Context of Malabar Migration: A Case Study of Taliparamba Block, Kannur District
}

\author{
Surabhi Rani \\ ${ }^{1}$ Dept.of Geography, Kannur University Payyanur Campus, Edat. P.O ,Payyanur, Kannur, Kerala
}

\begin{abstract}
Human Migration is considered as one of the important demographic process which has manifold effect on the society as well as to the individuals, apart from the other population dynamics of fertility and mortality. Several approaches dealing with migration has evolved the concepts related to the push and pull factors causing migration. Malabar Migration is a historical phenomenon of internal migration, in which massive exodus took place in the vast jungles of Malabar concentrating with similar socio-cultural-economic group of people. Various factors related to social, cultural, demographical and economical aspects initiated the migration from erstwhile Travancore to erstwhile Malabar district. The present preliminary study tries to focus over such factors associated with Malabar Migration in Taliparamba block of Kannur district (Kerala).This study is based on the primary survey of the study area and further supplemented with other secondary materials.
\end{abstract}

Keywords: migration, push and pull factors, Travancore, Malabar

\section{INTRODUCTION}

Human migration is one of the few truly interdisciplinary fields of research of social processes which has widespread consequences for both, individuals and the society. It is a sort of geographical or spatial mobility of people with change in their place of residence and socio-cultural environment.

Zelinsky,W.(1966) on territorial mobility, explains that migration is any permanent or semipermanent change of residence, more meaningfully, perhaps it is a spatial transfer from one social unit or neighborhood to another, which stains or ruptures previous social bonds.

Ogden P.E (1984) interpreted migration as a part of the wider study of population geography and as an important element in the understanding of the geographical organization of human society. Considering the overall concepts of migration, it can be generalized as migrants are those who move between the political units and movers are those who move within the political units. Thus at any given time the total population of a region can be divided into migrants and non-migrants, movers and non-movers. This classification establishes the mobility status of the population. (Cherunilam F.1987)

On the basis of the distance involved in the movement, periodicity, reasons, permanence and characteristics of movement, migration can be of several types like internal and international migration, permanent and temporary migration, voluntary and forced migration, chain and step migration.

A number of approaches developed in the past for analyzing the various dimensions of migration. The first study on migration was conducted by E.G Ravenstein in the 1880s .He introduced the "law of migration" that people usually move from rural areas to neighbouring urban centers seeking better and more employment opportunities.

Migration between two points will inversely be related to the distance and migrants will move by stages from nearby towns to distant lands. Ravenstein's laws were able to stand the test of time. However they contain mere generalizations without the underpinning of a theoretical framework. Following the lines of Ravenstein, E.S Lee (1966) put forth a set of general theories and hypotheses concerning migration. He tried to explain the spatial movement of people involving a set of factors at origin and destination and a set of intervening obstacles and also a series of personal factors. 
Migration was linked with the process of development in a model formulated by Arthur Lewis (1954) and subsequently extended and formulated by John Fei and Gustav Ranis(1961).

This model is a simple two sector model of the economics of labour transfer between the subsistence rural sector and the modern urban industrial sector. It is concerned with the process of transfer of labour from the traditional low productivity sector to modern high productivity sector of economy consequent upon the acceleration of economic activities in the modern industrial sector brought about by investment expansion.

Micheal Todaro (1969) has formulated another model suitable for analyzing migration originating in the context of rising unemployment. According to him any migration based on rational economic calculations, takes place in response to urban-rural differences in expected rather than actual earnings. According to him migration is possible even if there is unemployment in the urban sector. The model is applicable only to migration of labour towards urban destinations for paid employment.

Stouffer (1940) introduced the concept of intervening opportunities as an attempt to improve upon Zipf's principle of least effort. According to him the actual distance between two places is less important as a determinant of migration than the nature of space. He argued that the numbers of persons migrating from a given distance was directly proportional to the number of opportunities at that distance and inversely proportional to the number of intervening opportunities.

According to Wolport (1965) migration occurs "when the place utility", in a few location becomes greater than that of the present location. This approach is based on the behavior theory. He argued that the pattern of migration is a composite expression of human aspirations, needs and perceptions. $\mathrm{He}$ considered the human mobility behaviour as one of the several means for individuals seeking maximization of utility and wellbeing. On the basis of place utility the individual develops an action space consisting of all places to which he can move.

On the other hand migration system theory discusses that migration alters the social, cultural, economic and institutional conditions at both the sending and receiving ends-that is, the entire developmental space within which migration processes operate.

In this way, these approaches summarize the concepts related with migration and its various dimensions in time and space.

\section{Malabar Migration}

Malabar Migration refers to the large-scale migration of cultivators, from south central Kerala to northern regions of Kerala (generally known as Malabar region) in the 20th century. The migration started from early decades of 20th century and continued well into the late 1970s and early 1980s.It was the very kind of internal migration stimulated by the peasant groups of mainly Syrian catholic denomination largely from the three midland taluk of ErstwhileTravancore-Meenachili, Thodupuzha, and Muvattupuzha to uplift their status of living in the virgin forest lands of Malabar area(Tharakan, P. K.1984). The early settlements were established in the sub- mountainous region (High and mid lands) of Malabar as these virgin tracts were left uncultivated. It was the kind of chain migration because migrants follow one another to the place of destination after the information got from the early migrants. It is the area of interest that why did they want to settle in the vast, dense forest land of Malabar leaving their own roots in the native lands in spite of having several obstacles.

So this makes the major thrust for this present paper for analyzing factors behind migration on the basis of Lee's hypotheses of migration.

\section{STUDY AREA}

Taliparamba block has been selected for conducting the Preliminary study (Map.1a.) It lies between latitudes $11^{0} 54^{\prime} 52.13^{\prime \prime} \mathrm{N}$ to $12^{0} 16^{\prime} 37.59^{\prime \prime} \mathrm{N}$ and between longitudes $75^{0} 15^{\prime} 48.77^{\prime \prime} \mathrm{E}$ to $75^{\circ} 34^{\prime} 6.08^{\prime \prime} \mathrm{E}$. It has the area of556.10 sq.km. It consists of 13 gram panchayats and one municipality. (Fig.1b.) According to census 2011 it has a population of 3,54,208 persons which is comprised of 1,66,664 males and 1,87,544 females. 


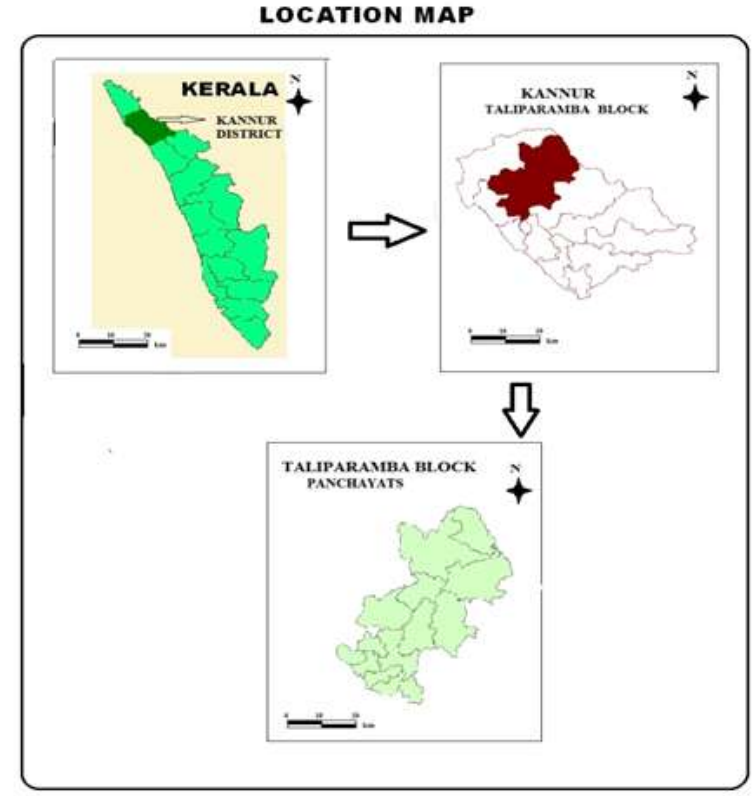

Map1(a). Location map of the study area

Most parts of this area are midland and highland regions composed of denudational structured hills, lower plateau, valley, residual hills and flood plains. This area has a humid climate with an oppressive hot season from March to the end of May. This is followed by the Southwest monsoon which continues till the end of September. October and November months get rainfall from the post Monsoon or retreating Monsoon season. The average annual rain fall is about $3300 \mathrm{~mm}$ and more than $80 \%$ of it occurs during the period of Southwest monsoon.

So total120 samples have been collected from the four Panchayats of the Taliparamba Block, namely Alakode, Udaygiri, Naduvil, and Chapparapadav ( high and mid land areas)proportionately covering 30 samples in each of the selected Panchayats.(Fig.1b.)The selection of study area for collecting samples is done due to the very fact that Migrants from early Travancore region were oriented to plantation economy and in hilly areas cultivable waste lands were available in comparative plenty.
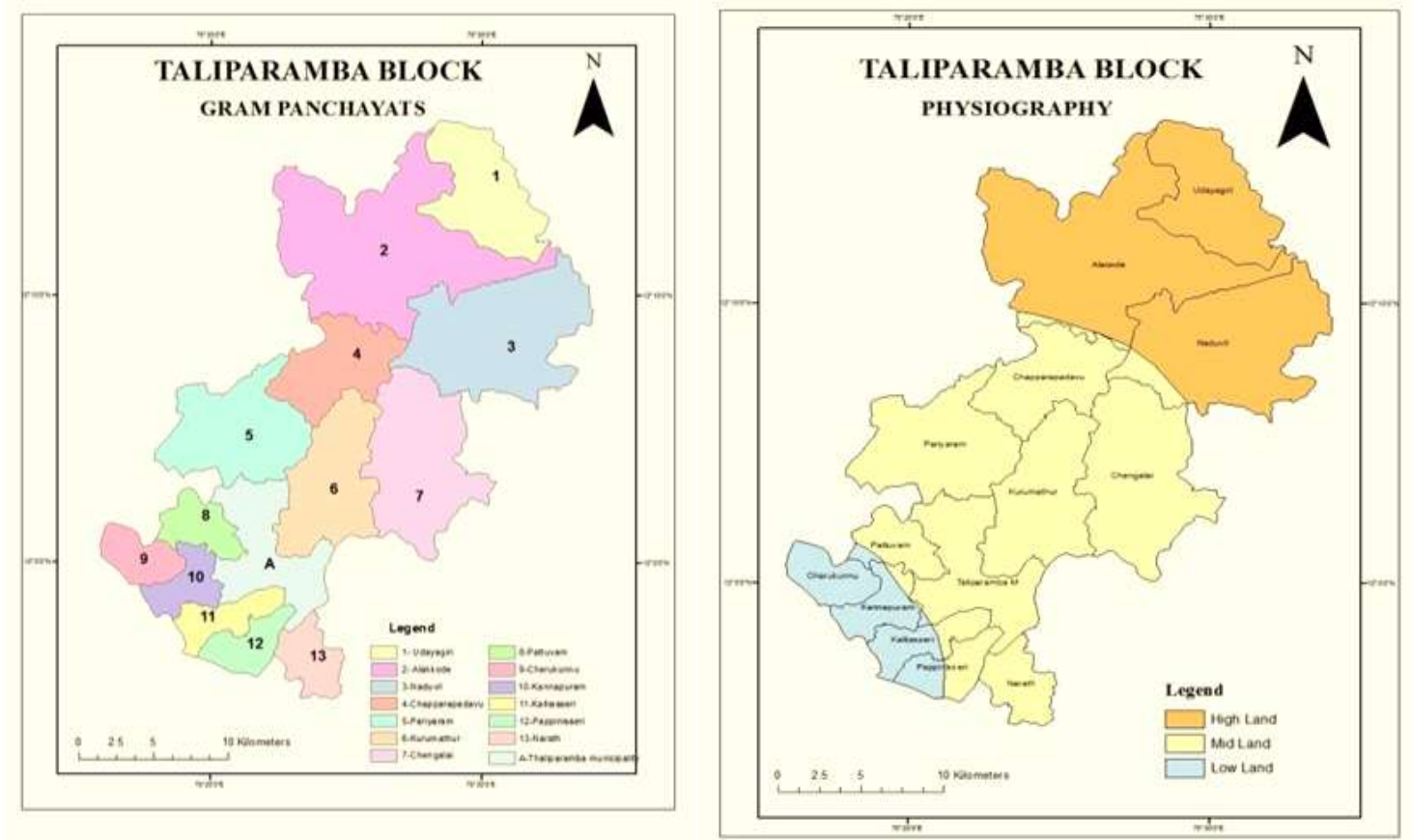

Fig1(b). Administrative and physiographic division of Study area 


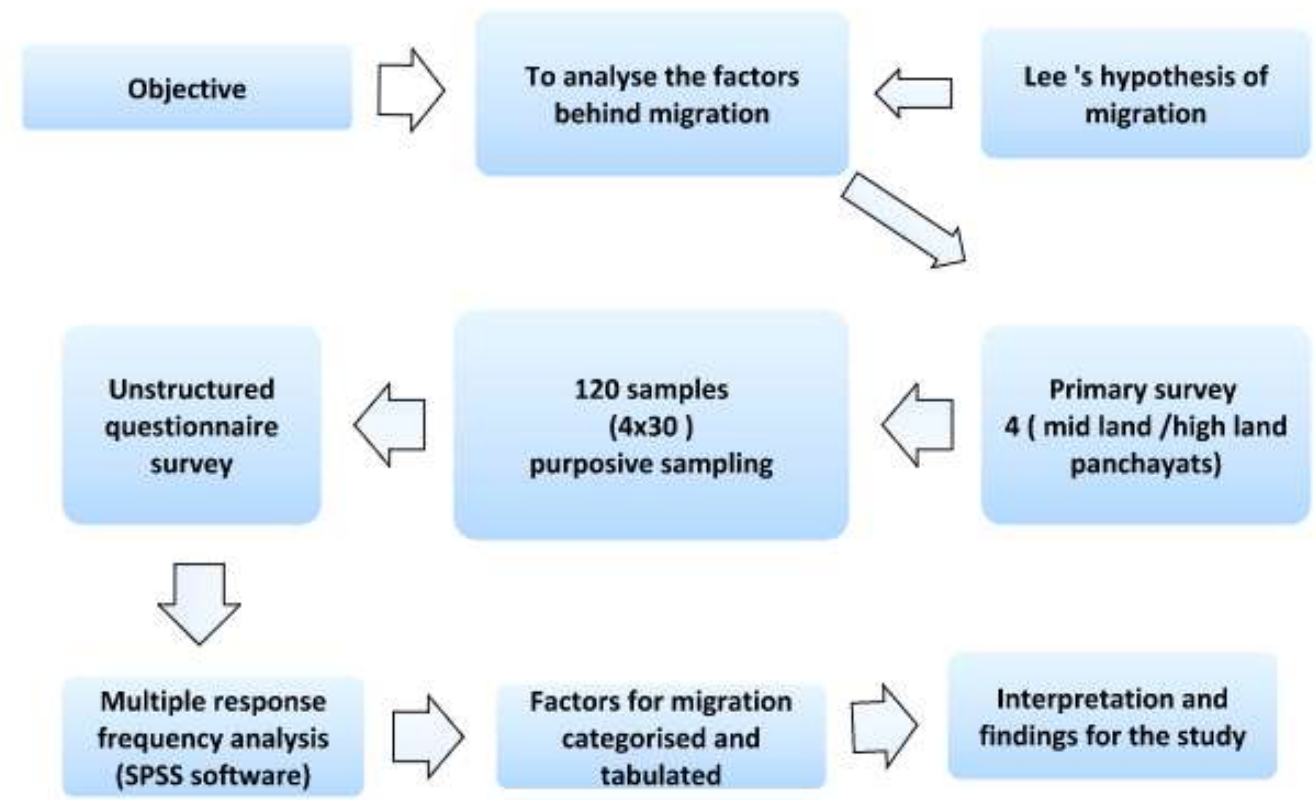

Fig1. Flowchart for methodology adapted for the study

\section{OBJECTIVE}

To analyse the underlying factors behind Malabar Migration.

\section{Data Sources And Methodology}

This study is based on the primary data sources collected through sample survey method. Total 120 samples based on the purposive sampling technique(non-probability sampling method) have been collected for conducting the preliminary study. The collection of primary data was done through the unstructured interview method. This study follows the retrospective study design as it investigates the phenomena happened in the past.

Analysis is done on the basis of the multiple responses for the questions gathered from the respondents during survey and thus multiple response frequency analysis for the factors causing migration has been done with the help of SPSS Software. The main methodological base for analysis is Lee's hypo these of migration which are being stated as below (lee, 1966).

Factors in the act of migration:

The factors which enter into the decision to migrate and the process of migration may be summarized under four headings, as follows:

1. Factors associated with the area of origin. 2. Factors associated with the area of destination. 3. Intervening obstacles. 4. Personal factors.

Based on the information gathered, findings were interpreted and supplemented with other literatures related with the study.

\section{RESULTS AND DISCUSSION}

On the basis of the foregoing discussions in the introduction part, it can be understood that migration is a function of the interplay of a number of push and pull factors. This study is concerned with the migration of peasants from Travancore region to Malabar. Normally all sections of traditional subsisting agricultural economy are proverbially rooted in their ancestral soils and have great aversion to any spatial/occupational mobility but this peculiar kind of migration took place to bring agro-socio changes and slowly stepped into capitalistic way of farming.

Although this migration paved its way in the early decades of $19^{\text {th }}$ century, but during the decades of 1940-70 this got momentum and a massive exodus took place in Malabar region of Kerala. As this study carries the objective of analyzing factors related to the Malabar Migration, so information gathered from the survey has been analyzed and tabulated below. 
Analysing Lee's Hypotheses of Migration in the Context of Malabar Migration: A Case Study of Taliparamba Block, Kannur District

TableI. Year of Migration

\begin{tabular}{|l|l|l|}
\hline \multicolumn{1}{|c|}{ Year } & \multicolumn{1}{|c|}{ No. of migrants } & \multicolumn{1}{c|}{ Percent } \\
\hline $1931-1940$ & 5 & 4.2 \\
\hline $1941-1950$ & 16 & 13.3 \\
\hline $1951-1960$ & 75 & 62.5 \\
\hline $1961-1970$ & 21 & 17.5 \\
\hline 1970 later & 3 & 2.5 \\
\hline Total & 120 & 100.0 \\
\hline
\end{tabular}

Based on Primary survey

Thus, Table I clearly illustrates that majority of persons migrated in the year of 1950-70, comprising more than $80 \%$ of the total samples. The reasons behind this is the increased population pressure in Travancore resulting shortage of land for partition among children, rise of agricultural produce during middle of thirties which fell down earlier due to great depression of 1929 and the increased information about the successful early migrants settled in the Malabar. This can be further understood by the following Table II which shows the decennial percentage increase in population for erstwhile Malabar and Travancore region. Increasing population at the place of origin (central Travancore) has contributed a lot to propel this migration process.

TableII. Decennial Percentage Increase in Population of Kerala State, District Roughly Corresponding to the Former Malabar District and Former Travancore State, 1901-1951

\begin{tabular}{|l|l|l|l|l|l|}
\hline & \multicolumn{5}{|c|}{ Percentage increase in Population } \\
\hline district & $1901-1911$ & $1911-1921$ & $1921-1931$ & $1931-1941$ & $1941-1951$ \\
\hline Cannanore & +7.9 & +2.8 & +15.2 & +12.6 & +22.4 \\
\hline Kozhikode & +7.5 & +3.5 & +16.8 & +12.2 & +27.6 \\
\hline Malappuram & +9.6 & +2.2 & +14.4 & +11.7 & +17.7 \\
\hline Palaghat & +7.3 & +4.2 & +10.2 & +8.9 & +18.5 \\
\hline Malabar region & +7.9 & +3.1 & +7.9 & +17.8 & +21.5 \\
\hline Kottayam & +17.9 & +16.1 & +37.0 & +21.8 & +22.6 \\
\hline Alleppy & +14.8 & +18.5 & +24.3 & +12.7 & +19.4 \\
\hline Quilon & +14.7 & +18.6 & +27.9 & +25.3 & +29.0 \\
\hline Trivandrum & +17.5 & +17.0 & +28.6 & +18.5 & +30.8 \\
\hline Ernakulam & +14.0 & +9.3 & +26.6 & +20.8 & +19.9 \\
\hline Travancore region & +15.6 & +15.7 & +28.4 & +19.5 & +24.1 \\
\hline
\end{tabular}

Source: Census of India, 1971, series-9, Kerala, part IIA, General population table, table A-II pp.56-57

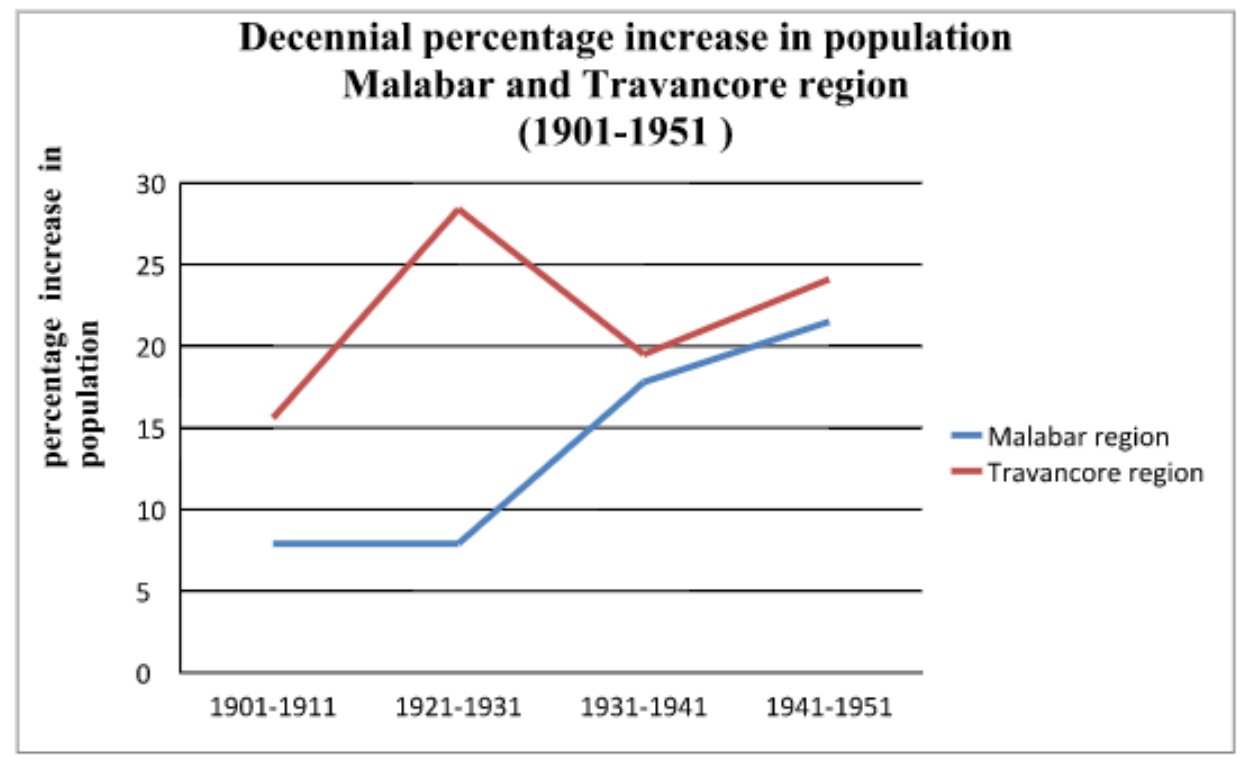

Fig2. Decennial percentage increase in population at Malabar and Travancore Region(1901-1951) 
Analysing Lee's Hypotheses of Migration in the Context of Malabar Migration: A Case Study of Taliparamba Block, Kannur District

The above Table II indicates that population growth was more in Travancore region than Malabar resulting increased pressure over the agricultural lands.

TableIII. Place of Origin in Migration Process

\begin{tabular}{|l|l|l|l|}
\hline \multicolumn{2}{|l|}{ Place of origin } & No. of migrants & Percentage \\
\hline \multirow{7}{*}{} & Kottayam & 76 & $63.3 \%$ \\
\cline { 2 - 4 } & Idukki & 21 & $17.5 \%$ \\
\cline { 2 - 4 } & Alapuzha & 13 & $10.8 \%$ \\
\cline { 2 - 4 } & Thrissur & 10 & $8.3 \%$ \\
\cline { 2 - 4 } & Pathanmitta & 0 & $0.0 \%$ \\
\cline { 2 - 4 } & Total & 120 & $100.0 \%$ \\
\hline
\end{tabular}

Based on primary survey

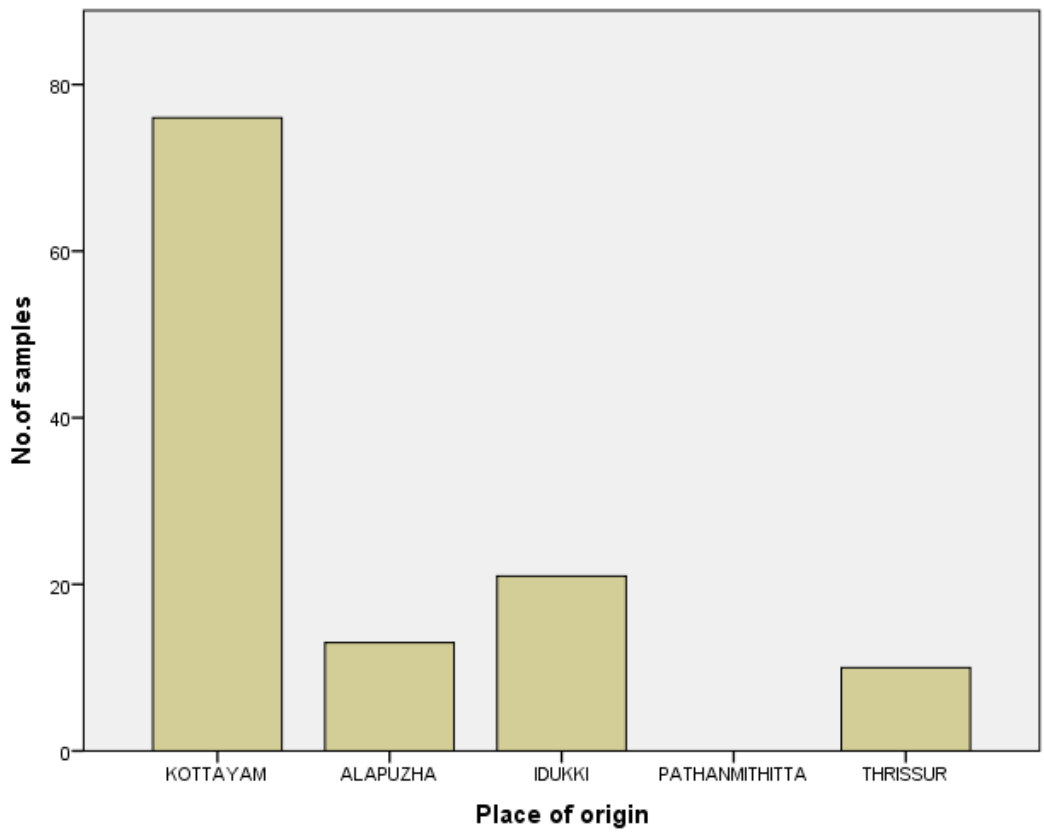

Fig3. Place of origin in migration process

From Table III it can be understood that most of the migrants has their place of origin in Kottayam and Idukki district collectively comprising of more than $80 \%$ of the samples which were the parts of erstwhile central Travancore state.

\section{FACtors of Migration Associated with the Malabar Migration}

Considering the Lee's hypothesis of migration and his propositions about factors associated with the area of origin, factors associated with the area of destination and intervening obstacles, this sample study also proposes the various factors associated with the place of origin and destination.

TableIV. Pull Factors at Place of Destination

\begin{tabular}{|l|ll|l|l|l|}
\hline \multirow{2}{*}{$\begin{array}{l}\text { Pull } \\
\text { factors }\end{array}$} & $\begin{array}{l}\text { Frequency } \\
\text { responses }\end{array}$ & $\begin{array}{l}\text { Percentage based } \\
\text { on respondents }\end{array}$ & $\begin{array}{l}\text { Percentage based on } \\
\text { responses }\end{array}$ \\
\cline { 2 - 6 } & $\bullet$ & Availability of cultivable land & 117 & $97.5 \%$ & $31.1 \%$ \\
\cline { 2 - 6 } & $\bullet$ & Low price of land & 77 & $64.2 \%$ & $20.5 \%$ \\
\cline { 2 - 6 } & $\bullet$ & More land for fragmentation & 59 & $57.5 \%$ & $18.4 \%$ \\
\cline { 2 - 6 } & $\bullet$ & Easy access to vast land & 30 & $43.3 \%$ & $13.8 \%$ \\
\cline { 2 - 6 } & $\bullet$ & Connection with jenmi & 26 & $25.0 \%$ & $8.0 \%$ \\
\cline { 2 - 6 } & $\bullet$ & Job availability at Destination & 5 & $21.7 \%$ & $6.9 \%$ \\
\cline { 2 - 5 } & Total respondents/responses & $120 / 376$ & $4.2 \%$ & $1.3 \%$ \\
\cline { 2 - 5 } & & & $100.0 \%$ & $100.0 \%$ \\
\hline
\end{tabular}

Based on primary survey 
The above Table IV shows that availability of abundant cultivable lands (unused lands having natural vegetation) and its easy access through Jenmies(Landlords),Low rate of lands compared to native place and personal motive of acquiring more lands were the major pull factors. Availability of cultivable land is the major pull factors for the migrants as $97 \%$ of the respondents answered for the same and this factor is of $31 \%$ of all the responses about pull factors.

Due to the opening of schools by the missionaries and churches, some people also migrated as being the teacher to the Malabar and further got settled here permanently with their families.

TableV. Push Factors at Place of Origin

\begin{tabular}{|c|ll|l|l|l|}
\hline \multicolumn{2}{|c|}{} & $\begin{array}{l}\text { Frequency } \\
\text { of responses }\end{array}$ & $\begin{array}{l}\text { Percentage based } \\
\text { on respondents }\end{array}$ & $\begin{array}{l}\text { Percentage based on } \\
\text { responses }\end{array}$ \\
\hline $\begin{array}{l}\text { Push } \\
\text { factors }\end{array}$ & $\bullet$ & Search for more land & 109 & $90.8 \%$ & $29.3 \%$ \\
\cline { 2 - 5 } & $\bullet$ & $\begin{array}{l}\text { Land fragmentation among } \\
\text { children }\end{array}$ & 78 & $65.0 \%$ & $21.0 \%$ \\
\cline { 2 - 6 } & $\bullet$ & High population in family & 76 & $63.3 \%$ & $20.4 \%$ \\
\cline { 2 - 6 } & $\bullet \quad$ Information from early migrants & 76 & $63.3 \%$ & $20.4 \%$ \\
\cline { 2 - 6 } & $\bullet$ & Poverty famine & 18 & $15.0 \%$ & $4.8 \%$ \\
\cline { 2 - 5 } & $\bullet$ & Idukki project & 7 & $6.7 \%$ & $2.2 \%$ \\
\cline { 2 - 5 } & $\bullet$ & Job placement & 0 & $5.8 \%$ & $1.9 \%$ \\
\cline { 2 - 5 } & $\bullet$ & Social structure at origin & $120 / 372$ & $100 \%$ & $0.0 \%$ \\
\cline { 2 - 5 } & Total respondents/responses & & $100.0 \%$ \\
\hline
\end{tabular}

Based on primary survey

Thus it can be understood from the table $\mathrm{V}$ that the increasing population in south-central part of Kerala resulting the pressure over agricultural lands, difficulties in fragmentation of lands among children, increasing price for lands, proposed Idukki water project were the major factors which insisted the people to migrate .Shortage of agricultural lands pushed the people in search of another cultivable lands despite of many obstacles, as people were engaged mostly in agricultural activities at that time for their livelihoods.

\section{INTERVENING OBSTACLES}

While migration may result from a comparison of factors at origin and destination, a simple calculus of positives and negatives does not decide the act of migration. The balance in favour of the move must be enough to overcome the natural inertia which always exists. Furthermore between every two points there stands a set of intervening obstacles which may be slight in some instances and insurmountable in others. The most studied of these obstacles is distance.

The following table shows the obstacles faced by migrants in the course of migration.

TableVI. Intervening Obstacles for the Migration

\begin{tabular}{|l|ll|l|l|l|}
\hline \multicolumn{2}{|c|}{} & $\begin{array}{l}\text { Frequency of } \\
\text { responses }\end{array}$ & $\begin{array}{l}\text { Percentage based } \\
\text { on respondents }\end{array}$ & $\begin{array}{l}\text { Percentage based on } \\
\text { responses }\end{array}$ \\
\hline \multirow{3}{*}{$\begin{array}{l}\text { Intervening } \\
\text { obstacles }\end{array}$} & $\bullet \quad$ Distance & 120 & $100.0 \%$ & $39.9 \%$ \\
\cline { 2 - 5 } & $\bullet \quad$ Lack of Transport facility & 120 & $100.0 \%$ & $39.9 \%$ \\
\cline { 2 - 6 } & $\bullet \quad$ Wild attacks & 41 & $34.2 \%$ & $13.6 \%$ \\
\cline { 2 - 6 } & $\bullet \quad$ Malaria/ailments & 20 & $16.7 \%$ & $6.6 \%$ \\
\cline { 2 - 5 } & Total respondents/responses & $120 / 301$ & $100.0 \%$ & $100.0 \%$ \\
\hline
\end{tabular}

Based on primary survey

It is illustrated from the Table VI that distance was the major intervening obstacle, people had to travel several kilometers to reach the destination in the time of inadequate facilities for transportation. Apart from this, wild animals, fever caused by malaria and other personal reasons created hindrance for the people. All of the respondents responded for the distance and lack of transport as intervening obstacles.

\section{Conclusion}

Thus Lee's conceptualization of migration which involves a set of factors at origin and destination, a set of intervening obstacles and a series of personal factors is a simple one which perhaps may be accepted for this primary study too. Apart from these, personal sensitiveness, intelligence and 
awareness of conditions at origin and destination depend upon personal contacts or upon sources of information which are also true in this context of study.

\section{REFERENCES}

[1] Zelinsky, W. (1966). A Prologue to Population Geography. New Jersey: Prentice Hall- Inc,Englewood Cliffs, pp.43-44

[2] Ogden, P. (1984). Migration and geographical change. London: Cambridge University Press, Cambridge.

[3] Cherunilam, F. (1987). Migration:causes,correlates,consequences,trends and policies. 7th ed. Bombay: Himalaya publishing house, pp.3-10.

[4] Ravenstein, E. (1889). The Laws of Migration. Journal of the Royal Statistical Society, vol.52, No.2,pp. 241-305.

[5] Lee, E. (1966). A Theory of Migration. Demography, vol.3.no.3, pp.47-48.

[6] Lewis. A. (1954), Economic Development with Unlimited Supplies of Labour. The Manchester School, vol.22, No.2. pp. 139-191.

[7] Gustav ranis and John C H Fei. (1961).A Theory of Economic Development.The American Economic Review, vol.51.No.4. pp.533-65.

[8] Todaro, M. (1969). A model of labour migration and urban employment in less developed countries. The American Economic Review, vol.59. No.1. pp.138-48.

[9] Stouffer, S. A. (1940). Intervening oppurtinities: A theory relating mobility and distance. American sociological review, Vol.5.No.6. pp.845-67.

[10] Zipf, G. K. (1949). Human behaviour and the principle of least effort:an introduction to human ecology. cambridge,Mass: Addison-wesley Press.pp.573.

[11] Wolpert, J. (1965). Behavioural aspects of the decision to migrate. Papers Of The Regional Science Association,pp. 159-169.

[12] Tharakan, P. K.(1984). Intra regional differences in agrarian systems and internal migration: a case study of the migrataion of farmers from Travancore to Malabar. [working paper 194] Centre for Development Studies, Trivandrum.

[13] Census of India, 1971, series-9,Kerala,part IIA, General population table, table A-II pp.56-57

Citation: Surabhi Rani. "Analysing Lee'S Hypotheses of Migration in the Context of Malabar Migration, A Case Study of Taliparamba Block, Kannur District ". International Journal of Research in Geography, vol 4, no. 1 2018, pp. 1-8. doi:http://dx.doi.org/10.20431/2454-8685.0401005.

Copyright: (C) 2018 Authors. This is an open-access article distributed under the terms of the Creative Commons Attribution License, which permits unrestricted use, distribution, and reproduction in any medium, provided the original author and source are credited. 